\title{
Antiretroviral Therapy Adherence in Persons with HIV/AIDS in Cuba
}

\author{
Carlos Aragonés BEng MS, Lizet Sánchez MS PhD, Jorge R. Campos, Jorge Pérez MD MS
}

\begin{abstract}
INTRODUCTION Cuba has an HIV prevalence of $0.1 \%$ in the population aged 15 to 49 years, very low despite increased incidence in recent years. In 2001, domestically-produced generic antiretroviral therapy was introduced and there has been complete coverage since 2003. In 2006, 1986 people with HIVIAIDS were receiving ART; by 2009, that figure reached 5034. Adherence to antiretroviral therapy is fundamental: nonadherence leads to treatment failure, development of resistance, progression to AIDS, and death.
\end{abstract}

OBJECTIVE Measure levels of treatment adherence and its predictive factors in persons with HIVIAIDS receiving antiretroviral therapy in 2006 in Cuba.

METHODS A cross-sectional study was carried out in 2006 of $\mathrm{Cu}$ ban HIV-positive individuals receiving antiretroviral therapy. A sample size of 876 was calculated using two-stage sampling (first by strata, and then by simple random sampling in each stratum). An anonymous structured questionnaire was administered to participants. Reporting of doses taken on each of the three days and in the week preceding the survey was recoded into five categories. Participants were considered highly adherent if they reported taking $\geq 95.0 \%$ of their medication as prescribed. Reasons for nonadherence were described and logistic

\section{INTRODUCTION}

AIDS is a leading cause of death in the Caribbean, where HIV prevalence is high.[1] However, Cuba maintains a prevalence of $0.1 \%$ in the population aged 15 to 49 years,[2] considered very low, even though incidence has increased in recent years.[1] From 1986 through 2009, 12,217 persons were diagnosed with HIV infection; 4938 (40.4\%) developed AIDS; and 2127 (17.4\%) died from AIDS. The epidemic has affected mainly men (81\% of total); and men who have sex with men (MSM) account for $72 \%$ of all HIV diagnoses.[2]

From 1986 through 1993, HIV-positive Cubans were admitted and treated exclusively at 14 sanatoria established in various provinces, $[3,4]$ a strategy that provoked considerable controversy.[5-8] Opportunistic infections and other HIV-associated conditions were treated at the Pedro Kourí Tropical Medicine Institute (IPK, its Spanish acronym). At the end of 1993, an ambulatory program was established,[3] and since 2006, major effort has gone into strengthening comprehensive decentralized care for HIVIAIDS patients at the primary health care level.[2]

In 1987, zidovudine (AZT) was recommended as monotherapy for all persons with AIDS in Cuba. In 1996, the Ministry of Public Health (MINSAP, its Spanish acronym) acquired antiretroviral drugs (ARVs) for all children with AIDS and their mothers (zidovudine, lamivudine, and indinavir). Since 1997, HIV-positive pregnant women receive AZT to prevent mother-to-child transmission. In 1998, international donations of zidovudine, lamivudine, didanosine, zalcitabine, stavudine, saquinavir, ritonavir, and indinavir enabled a group of persons with AIDS to begin receiving these ARVs. In mid-2001, several domestically-produced ARVs regression modeling used to develop hypotheses on associations between high adherence and its predictive factors.

RESULTS Interviews were obtained with 847 individuals, $70.6 \%$ of whom self reported high adherence. There were no significant differences between highly adherent and less adherent patients with regard to sex, place of residence, treatment setting, time of diagnosis, or length of treatment. Variables associated with high adherence were communication with the specialist physician, change in treatment, memory, self-efficacy, as well as commitment to and opinions about treatment.

CONCLUSIONS In Cuba, where treatment is free of charge to patients, adherence is good. Treatment adherence might be improved by achieving a closer doctor-patient relationship; taking measures to motivate patients and promote self-efficacy and commitment to treatment; publicizing treatment outcomes; and providing assistance to patients to help them remember their medication schedule. Further studies are required to determine current adherence levels; and longitudinal research to determine adherence over time.

KEYWORDS HIV, AIDS, antiretroviral therapy, medication adherence, compliance, Cuba

were introduced (zidovudine, lamivudine, stavudine, didanosine, and indinavir, followed a few months later by nevirapine), which were first prescribed for people diagnosed with AIDS or who were critically ill. In 2002, the treatment group was enlarged, and since 2003 , there has been $100 \%$ coverage for all who require it, as defined by: CD4 cell count $<350$ cells $/ \mathrm{mm}^{3}$, viral load $>55,000$ copies $/ \mathrm{mL}$, and presence of an opportunistic infection.[3] Later, drug combinations were expanded with support from the Global Fund to Fight AIDS, Tuberculosis, and Malaria.[4] At the end of 2009, 5034 persons with HIVIAIDS were receiving ARVs.[2] Several studies have shown that this use of antiretroviral therapy (ART) in Cuba has increased survival time and reduced opportunistic infections and AIDS deaths. [2,3,9,10]

ART adherence is a key factor in disease course in persons with HIVIAIDS.[9-11] Adherence of $\geq 95.0 \%$ can achieve suppression of viral load to undetectable levels, improve immune system function,[9,12,13] and reduce AIDS-related morbidity and mortality.[14] In contrast, nonadherence can lead to treatment failure, development of ARV-resistant viral strains,[15] progression to AIDS[16] and death.[17] Factors related to patient characteristics, social environment, treatment type, the disease itself, and the health care team can influence degree of treatment compliance.[11,18-21]

In Cuba, clinicians have customarily explored treatment adherence through general patient interviews and monitoring of CD4 lymphocytes and viral load. However, some authors consider this method imprecise.[22,23] Although ART outcomes-fewer opportunistic infections, longer survival time, and fewer deaths-could lead to a conclusion of optimal adherence in Cuba,[3] no national study has been carried out to measure adherence. 
The objective of this study is to determine high adherence and its predictive factors among Cuban HIV-positive individuals receiving ART.

\section{METHODS}

A cross-sectional study was done of 1986 HIV-positive individuals receiving ART in 2006. A stratified random sample was used, based on province of origin, sex, and treatment setting (outpatient care or sanatorium). The number of participants in each stratum was selected with probability proportional to its size. Participants in each stratum were selected by simple random sampling from the national list in SIDATRAT, a computer program designed by IPK for monitoring ART.

A minimum sample size of 694 individuals was determined using Epi Info 6.04 (expected prevalence of high adherence: $50 \%$, given that there were no prior studies on ART adherence in Cuba; margin of error: $3 \%$; confidence level: $95 \%$ ). Sample size was increased by $25 \%$ to 867 , to allow for refusals to participate and people who were sick, hospitalized, convalescing, away from their province, or deceased. General patient data were obtained from SIDATRAT.

Recruitment was limited to participants aged $>15$ years and who had been receiving ART for at least six months. The ethics committee at IPK, where all these patients were regularly seen, approved the study protocol. Informed consent was obtained from all participants.

Those selected were given a self-administered, anonymous, structured questionnaire. Respondents with a low educational level were assisted by trained personnel.

The questionnaire was developed based on a review of medical literature reporting relevant survey tools,[9,11,24-31] results of focus groups with patients and professionals, and interviews with AIDS experts. Questionnaire development included a pilot study with persons with HIVIAIDS who attended the IPK outpatient clinic; pilot results were analyzed by AIDS experts. Responses used a 5-point Likert scale, with a Cronbach's alpha of 0.93 , indicating high internal consistency. The questionnaire took approximately 15 minutes to complete. Interobserver reliability and concurrent validity were considered acceptable.

Questionnaire items were grouped by: 1) memory-ability to remember to take medications on schedule; 2) quality of communication with the physician at the specialized HIVIAIDS clinic; 3) quality of communication with family doctor; 4) support from and quality of communication with family; 5) support from and quality of communication with friends and classmates or co-workers; 6) self-efficacy_feeling capable of complying with treatment requirements; 7) commitment to complying with prescribed treatment; 8) agreement with positive opinions among persons with HIVIAIDS in Cuba regarding treatment effectiveness, trust in physicians, and confidence in the health system; 9) treatment compliance on each of the three days and in the week preceding questionnaire administration; and 10) compliance with nutritional requirements on each of the three days and in the week preceding questionnaire administration.

Each patient was asked for information on: 1) sociodemographic characteristics (age, sex, educational level, province of resi- dence); 2) HIV (year of diagnosis, care setting-outpatient or sanatorium); and 3) treatment (years of ART, changes in drug combinations, names of drugs in current combination, number of doses daily, and number of tablets daily).

Adherence based on self-reporting of number of doses taken on each of the three days and in the week prior to questionnaire administration[25,29,32-35] was recoded into five categories:

1) perfect adherence $(100 \%)$,

2) good adherence (95.0-99.9\%),

3) moderate adherence (80.0-94.9\%),

4) poor adherence $(1.0-79.9 \%)$, and

5) treatment drop-out $(<1.0 \%) .[35,36]$

A participant was considered highly adherent if reported adherence was good or perfect ( $\geq 95.0 \%)$.[36]

Data analysis was done using SPSS 11.5 software. Contingency tables were constructed and data described using absolute and relative frequencies. The chi-square test of independence was used to assess possible associations between patient classification as adherent or nonadherent and other study variables. The reasons most frequently mentioned by individuals whose adherence was poor or who dropped out of treatment were listed.

After using the Spearman correlation coefficient to test for multicollinearity (among sociodemographic variables, and variables regarding HIV and treatment; memory; relationship with specialist clinical physician; support of family, friends, classmates and coworkers; self-efficacy; commitment to treatment; and agreement with positive opinions among persons with HIVIAIDS about confidence in treatment), logistic regression models were constructed to simultaneously evaluate above factors associated with high adherence.

To gain efficiency and clarity in the interpretation of results, continuous variables-relationship with specialist, with family, with friends, self-efficiency, commitment, agreement with circulating opinions, and memory-were transformed into dichotomous variables, using the median as the cutoff point.[37] Values above the median were considered adequate or functional, using the nonfunctional values as reference for analysis. Categorical values were converted into dummy values, taking the first value as the reference category. The Hosmer-Lemeshow test was used to analyze model fit[38] and the model constant adjusted.

\section{RESULTS}

The response rate was $97.7 \%$ (847/867). Most interviewees $(97.8 \%)$ self-administered the questionnaire; a small group $(2.2 \%)$ with low educational level received assistance from trained personnel.

Mean respondent age was 35.8 years, and $77.6 \%$ were men. Distribution by region of residence was as follows: $19.8 \%$ from the Eastern region (provinces of Granma, Guantánamo, Holguín, Las Tunas, and Santiago de Cuba); $31.3 \%$ from the Central region (provinces of Camagüey, Ciego de Avila, Cienfuegos, Sancti Spíritus, and Villa Clara); and $48.9 \%$ from the Western region (provinces of Havana, Havana City, Matanzas and Pinar del Río). With regard to educational level, $8.1 \%$ had 
completed university studies, 9.4\% technical level studies, $32.9 \%$ high school, $39.2 \%$ junior high school, and $8.0 \%$ primary school, while $2.2 \%$ had not completed primary education. Of the total, $25.1 \%$ were inpatients in a sanatorium, and $74.9 \%$ in ambulatory care.

Diagnosis occurred from 1986 through 1995 in $22.1 \%$ of respondents, from 1996 through 2000 in $46.7 \%$, and in 2001 or later in $31.2 \%$. Mean length of time on ART was 2.3 years. ART regimen had changed for $42.6 \%$ of respondents. Mean number of tablets taken daily was $12.8 ; 43.3 \%$ took medication twice a day; $16.0 \%$, three times a day; and $40.7 \%$, four or more times a day.

Perfect adherence was reported by $62.6 \%$ of respondents; good by $8.0 \%$; moderate by $14.1 \%$; poor by $13.3 \%$; and $2.0 \%$ had dropped out of treatment. Thus, $70.6 \%$ of study participants were considered highly adherent. Bivariate analysis did not find significant differences between highly adherent and less adherent respondents with regard to sex, region of residence, treatment setting (sanatorium or outpatient), time of diagnosis, or years in treatment. Adherence decreased as number of tablets $(p=0.046)$ and doses per day $(p=0.050)$ increased (Table 1$)$.

The five most frequent reasons mentioned by respondents whose adherence was poor or who dropped out of treatment were: the attending physician did not understand how hard it can be to take the medication; friends and co-workers did not remind them to take it; they didn't feel they could take it life-long; the treatment interrupted daily activities; and friends, classmates and co-workers did not spend enough time with them to talk about the illness and treatment (Table 2).

Using the Spearman rank correlation coefficient, multicollinearity was found between the number of tablets daily and the number of doses daily (Spearman coefficient $0.823, p<0.001$ ), so number of doses was dropped from the model. The HosmerLemeshow goodness-of-fit test for the logistic regression model showed that it can be considered acceptable with no evidence of an important difference between predicted and observed results $\left(x^{2}=7.053, \mathrm{gl}=8, \mathrm{p}=0.531\right)$.

Change in treatment increased the probability of high adherence 1.6 times and supportive communication with a specialist physician 1.5 times. Good memory, self-efficacy, commitment, and agreement with positive opinions on confidence in doctors and health system increased probability of high adherence 3.2, 3.0, 1.6 and 1.8 times, respectively (Table 3 ).

\section{DISCUSSION}

As in other countries, in Cuba the use of ART in HIV-positive individuals has led to a decrease in opportunistic diseases and deaths from AIDS. $[3,8]$ This achievement requires a high degree of adherence to treatment. A limitation of this study is that it is cross-sectional; therefore, the temporal relationship among variables studied is unknown and associations observed cannot be interpreted as causal.

Furthermore, the number of years of treatment studied is small, since ART has been guaranteed for all persons needing it since 2003, and our study was carried out in 2006. However, the research allows us to hypothesize about factors that may be associated with adherence.

Table 1: Characteristics of study participants and high adherence to antiretroviral therapy $(n=847$ except as noted)

\begin{tabular}{|c|c|c|c|c|}
\hline \multicolumn{5}{|c|}{ ART Adherence } \\
\hline Characteristic & Total & $\begin{array}{l}\text { Highly Adherent } \\
\text { Patients } \\
\text { n (\%) }\end{array}$ & $\begin{array}{c}\text { Nonadherent } \\
\text { Patients } \\
\text { n (\%) }\end{array}$ & $\begin{array}{c}\mathbf{p} \\
\text { Value }\end{array}$ \\
\hline $\begin{array}{l}\text { Sex } \\
\text { Female } \\
\text { Male }\end{array}$ & $\begin{array}{l}190 \\
657\end{array}$ & $\begin{array}{l}129(67.9) \\
469(71.4)\end{array}$ & $\begin{array}{r}61(32.1) \\
188(28.6)\end{array}$ & 0.352 \\
\hline $\begin{array}{l}\text { Age group (years) } \\
<25 \\
25-34 \\
35-44 \\
45-54 \\
\geq 55\end{array}$ & $\begin{array}{r}66 \\
332 \\
334 \\
84 \\
31\end{array}$ & $\begin{array}{r}41(62.1) \\
210(63.3) \\
259(77.5) \\
64(76.2) \\
24(77.4)\end{array}$ & $\begin{array}{r}25(37.9) \\
122(36.7) \\
75(22.5) \\
20(23.8) \\
7(22.6)\end{array}$ & 0.000 \\
\hline
\end{tabular}

\section{Residence}

(region of Cuba)

$\begin{array}{lllll}\text { Center } & 265 & 194(73.2) & 71(26.8) & 0.082\end{array}$

West $\quad 414 \quad 297(71.7) \quad 117(28.3)$

East

$168 \quad 107(63.7) \quad 61(36.3)$

Educational level ${ }^{\mathrm{b}}$

Incomplete Primary

Primary

Junior High School

High School

Technical School

University

Treatment setting

Outpatient
Sanatorium

Time of diagnosis

1986-1995

1996-2000

2001 or later

Years of treatment

$\leq 1$

$>1$ to $\leq 2$

$>2$ to $\leq 5$

$>5$

$19 \quad 16(84.2)$

$3(15.8) \quad 0.023$

$\begin{array}{lll}198 & 38(55.9) & 30(44.1)\end{array}$

332

279

$228(68.7)$

$205(73.5)$

$104(31.3)$

80

69

$63(78.7)$

$74(26.5)$

$17(21.3)$

$21(30.4)$ $48(69.6)$

$179(28.2)$

$\begin{array}{llll}634 & 455(71.8) & 179(28.2) & 0.199\end{array}$

$213 \quad 143(67.1) \quad 70(32.9)$

187

396

264

$141(75.4)$

$268(67.7)$

$46(24.6) \quad 0.147$

264

$189(71.6)$

$128(32.3)$

$75(28.4)$

\begin{tabular}{|c|c|c|c|c|}
\hline $\begin{array}{l}\text { Change in } \\
\text { treatment }^{\mathrm{a}} \\
\text { No } \\
\text { Yes }\end{array}$ & $\begin{array}{l}486 \\
361\end{array}$ & $\begin{array}{l}320(65.8) \\
278(77.0)\end{array}$ & $\begin{array}{r}166(34.2) \\
83(23.0)\end{array}$ & 0.000 \\
\hline $\begin{array}{l}\text { Tablets daily }{ }^{b c} \\
\leq 13 \\
>13 \text { to } \leq 16 \\
>16\end{array}$ & $\begin{array}{l}437 \\
226 \\
173\end{array}$ & $\begin{array}{l}322(73.7) \\
158(69.9) \\
110(63.6)\end{array}$ & $\begin{array}{r}115(26.3) \\
68(30.1) \\
63(36.4)\end{array}$ & 0.046 \\
\hline $\begin{array}{l}\text { Times a day } \\
\text { medication taken } \\
2 \\
3 \\
\geq 4\end{array}$ & $\begin{array}{l}362 \\
134 \\
340\end{array}$ & $\begin{array}{r}270(74.6) \\
95(70.9) \\
225(66.2)\end{array}$ & $\begin{array}{r}92(25.4) \\
39(29.1) \\
115(33.8)\end{array}$ & 0.050 \\
\hline
\end{tabular}

${ }^{a} \mathrm{p}<0.001$

${ }^{b} p<0.05$

'Data unavailable for 11 patients

According to several authors, determining adherence through patient self-report is useful,[9,37,39,40] reliable,[41] and correlates well with virologic response.[36] Others are more cautious about reliability, noting that good adherence is socially acceptable and respondents may tend to exaggerate compliance.[32,36] In this study, $70.6 \%$ of patients were highly adherent. Overestimate for the reasons above cannot be ruled out. 
Table 2: Participant self-reported reasons for poor adherence $(n=113)$ or treatment drop-out $(n=17)$

\begin{tabular}{|c|c|c|c|}
\hline Reason & $\begin{array}{c}\text { Treatment Dropout } \\
\mathrm{n}(\%)\end{array}$ & $\begin{array}{c}\text { Poor Adherence } \\
n(\%)\end{array}$ & $\begin{array}{l}\text { Total } \\
\text { n (\%) }\end{array}$ \\
\hline Friends and classmates/coworkers don't remind me to take my medications & $11(64.7)$ & $39(34.5)$ & $50(38.5)$ \\
\hline My treatment interrupts other daily activities & $5(29.4)$ & $35(31.0)$ & $40(30.8)$ \\
\hline $\begin{array}{l}\text { Friends and classmates/coworkers don't spend enough time with me to talk about my } \\
\text { illness and treatment }\end{array}$ & $9(52.9)$ & $28(24.8)$ & $37(28.5)$ \\
\hline Friends and classmates/coworkers don't help me cope with the drugs' side effects & $8(47.1)$ & $27(23.9)$ & $35(26.9)$ \\
\hline I don't want to hear about medications or treatments & $9(52.9)$ & $24(21.2)$ & $33(25.4)$ \\
\hline I believe the treatment does more harm than good & $9(52.9)$ & $23(20.4)$ & $32(24.6)$ \\
\hline My family doesn't spend enough time with me to talk about my illness and treatment & $6(35.3)$ & $26(23.0)$ & $32(24.6)$ \\
\hline I don't believe it is that important to be strict about taking the medications & $8(47.1)$ & $23(20.4)$ & $31(23.8)$ \\
\hline I forget to take my medications & $5(29.4)$ & $25(22.1)$ & $30(23.1)$ \\
\hline I don't take the medications if I am feeling sick & $2(11.8)$ & $16(14.2)$ & $18(13.8)$ \\
\hline
\end{tabular}

Table 3: Logistic regression model for sociodemographic variables and factors associated with ART adherence of $\geq 95 \%(n=847)$

\begin{tabular}{|c|c|c|c|c|}
\hline \multirow[t]{2}{*}{ Factors } & \multirow[t]{2}{*}{ OR } & \multicolumn{2}{|c|}{$\begin{array}{c}\text { 95\% Confidence } \\
\text { Interval }\end{array}$} & \multirow[t]{2}{*}{ p Value } \\
\hline & & Lower & Upper & \\
\hline $\begin{array}{l}\text { Sex } \\
\text { Female sex }\end{array}$ & 0.904 & 0.584 & 1.400 & 0.650 \\
\hline $\begin{array}{l}\text { Educational level } \\
\text { Incomplete Primary } \\
\text { Primary } \\
\text { Secondary } \\
\text { High School } \\
\text { Technical School } \\
\text { University }\end{array}$ & $\begin{array}{l}3.771 \\
0.673 \\
1.094 \\
1.178 \\
1.031\end{array}$ & $\begin{array}{l}0.713 \\
0.311 \\
0.627 \\
0.648 \\
0.460\end{array}$ & $\begin{array}{r}19.945 \\
1.456 \\
1.908 \\
2.143 \\
2.309\end{array}$ & $\begin{array}{l}0.118 \\
0.315 \\
0.752 \\
0.591 \\
0.941 \\
0.385\end{array}$ \\
\hline $\begin{array}{l}\text { Age group (years) } \\
<25 \\
25-34 \\
35-44 \\
45-54 \\
\geq 55\end{array}$ & $\begin{array}{l}0.634 \\
1.081 \\
0.732 \\
0.672\end{array}$ & $\begin{array}{l}0.358 \\
0.609 \\
0.342 \\
0.224\end{array}$ & $\begin{array}{l}1.123 \\
1.919 \\
1.568 \\
2.021\end{array}$ & $\begin{array}{l}0.114 \\
0.118 \\
0.790 \\
0.422 \\
0.480\end{array}$ \\
\hline $\begin{array}{l}\text { Treatment setting } \\
\text { Outpatient }\end{array}$ & 0.976 & 0.653 & 1.460 & 0.906 \\
\hline $\begin{array}{l}\text { Time of diagnosis } \\
\text { 1986-1995 } \\
1996-2000 \\
2001 \text { or later }\end{array}$ & $\begin{array}{l}0.656 \\
0.834\end{array}$ & $\begin{array}{l}0.414 \\
0.506\end{array}$ & $\begin{array}{l}1.038 \\
1.374\end{array}$ & $\begin{array}{l}0.171 \\
0.072 \\
0.475\end{array}$ \\
\hline $\begin{array}{l}\text { Change in treatment } \\
\text { Yes }\end{array}$ & 1.597 & 1.083 & 2.358 & 0.018 \\
\hline $\begin{array}{l}\text { Number of tablets daily } \\
\leq 13 \\
>13 \text { to } \leq 16 \\
>16\end{array}$ & $\begin{array}{l}0.908 \\
0.797\end{array}$ & $\begin{array}{l}0.582 \\
0.501\end{array}$ & $\begin{array}{l}1.417 \\
1.267\end{array}$ & $\begin{array}{l}0.629 \\
0.671 \\
0.338\end{array}$ \\
\hline $\begin{array}{l}\text { Relationship with specialist } \\
\text { physician }\end{array}$ & 1.457 & 1.010 & 2.103 & 0.044 \\
\hline Family support & 0.832 & 0.556 & 1.246 & 0.372 \\
\hline Friends' support & 1.327 & 0.882 & 1.998 & 0.175 \\
\hline Self-efficacy & 2.976 & 1.999 & 4.433 & 0.000 \\
\hline Commitment & 1.597 & 1.093 & 2.334 & 0.016 \\
\hline $\begin{array}{l}\text { Agreement with positive } \\
\text { opinions/confidence }\end{array}$ & 1.817 & 1.245 & 2.650 & 0.002 \\
\hline Memory & 3.175 & 2.112 & 4.774 & 0.000 \\
\hline
\end{tabular}

Adherence measurement methods vary widely, and thus produce results difficult to compare. For example, percent of "adherent persons" has been reported in Brazil as 63.1\%[42] and $56.9 \%$;[43] in Italy 57\%;[44] in France $29.1 \%[45]$ and 55$60 \% ;[46]$ in South Africa 93.6\%;[47] in Botswana 54\%;[48] in Uganda 89\%[49] and 85\%;[50] in Thailand 69\%;[37] and in the United States 50\%.[13]

New treatment regimes, available primarily in developed countries, with fewer numbers of tablets and doses daily, have contributed to increased adherence where these are available, although these studies such as those above indicate that adherence remains a problem even in some of those countries.

In our study, no association was found between adherence and sex, which coincides with some investigations,[24,37,43,51] but not others.[18,20,42] Lack of significant differences in adherence among regions in Cuba may be explained by existence of a national HIVIAIDS program with a unified approach. However, possible differences at the provincial and municipal levels should be explored to optimize intervention effectiveness in improving treatment adherence. We did not observe a significant difference between adherence in outpatient and sanatorium settings, suggesting the need for further research on this, particularly on the subjective factors concerning relationships with family, friends and the medical team.[18]

Our findings differ from some studies showing adherence increasing with age[52] and higher educational level.[24,43] While these did appear to have an influence in bivariate analysis, the association disappeared with multivariate analysis. Nevertheless, it would be prudent to tailor support to the age and educational levels of persons with HIV.

Some studies have associated non-adherence to change in treatment.[41] In contrast, our study found persons who have changed treatment to be more adherent. This might be related to the limitation of a cross-sectional study, although it is also possible that the change in treatment was because the individuals were in worse 
health and so felt the severity of the disease more strongly.[53] It could also be that the treatment change was to an easier-to-use regime with fewer tablets. While we did not find an effect of number of tablets in the multivariate analysis, several authors have reported that adherence decreases with an increase in the number of tablets and the number of daily doses.[24,43,54]

Adherence is clearly a challenge for both health professionals and the HIVIAIDS community. Although the number who dropped out of treatment (17 individuals in the sample) seems very low, it means there are dozens of HIV-positive people who could be at risk of becoming ill or dying. Persons who dropped out of treatment or had poor adherence most frequently referred to communications problems with the attending physician and lack of support from family and friends as reasons for their nonadherence. Also mentioned were lack of self-efficacy, disruption of daily activities, forgetfulness, and influence of negative opinions toward antiretroviral therapy,[39,40,53,55,56] all of which therefore should be taken into account in planning personalized interventions, specialized counseling, and training programs for health promoters.

In Cuba, individuals with HIVIAIDS more frequently voice opinions on negative aspects of therapy, such as adverse reactions, lipodystrophy, inconvenience, and number of tablets, than on positive results of therapy, such as increased survival time and well-being, and decrease in opportunistic infections. $[2,3,8]$ This leads to the importance of continuing to publicize positive results of ART within the HIVIAIDS community.

The positive association between high adherence and goof communication with the specialist physician is an important aspect to keep in mind - though we should clarify that at the time of this study, family physicians did not yet play an important role in follow-up of persons on ART. A qualitative study of adherence in Brazil found that health professionals caring for persons with HIVIAIDS are often overworked and have little time to talk with patients about their needs and problems related to therapy and adherence.[53]

MINSAP's National HIVIAIDS Program has provided training for physicians working with HIV-positive persons,[2] efforts which should continue and be expanded. There still may be untapped potential in improving the doctor-patient relationship in Cuba, such as training health workers in more effective techniques to assist in nonjudgmental discussions with patients about adherence and adverse reactions.
The study's multivariate analysis found no association between adherence and support from family, friends, and classmates/ coworkers. This is perhaps surprising, since social networks have been shown to play an important role in general in the lives of people with HIVIAIDS.[21,37] Observations from clinical practice suggest social support can influence memory and self-efficacy, elements which have shown to improve adherence in some settings. Longitudinal research on social networks and adherence in Cuba is needed to clarify the relationship of social networks to adherence.

Our results indicate that more effective mechanisms are also required to help patients remember their medication schedule.[56]

Two highly significant factors in achieving adherence of $\geq 95 \%$ are self-efficacy and commitment to treatment,[57] pointing to importance of programs that aim to increase self-esteem in persons with HIVIAIDS; help them feel capable of following their prescribed ART regimen and integrating it into their daily routine; learn more about ART therapy; and build motivation to remember and take the ARV medications in any setting.

\section{CONCLUSIONS}

This study examined the complex, multidimensional nature of adherence to retroviral treatment. While ARV adherence in Cuba is good, achieving perfect adherence remains a challenge. Facilitating a close doctor-patient relationship, motivating persons with HIVIAIDS, increasing their self-efficacy and commitment to treatment, publicizing positive ART outcomes, and assisting them to remember medication schedules are crucial tools for reaching this objective. We need more studies, particularly longitudinal ones, on factors affecting ARV adherence to improve medical care and quality of life of persons with HIVIAIDS in Cuba.

\section{ACKNOWLEDGMENTS}

The authors are grateful for the cooperation of study participants, members of GPSIDA, the Comprehensive Care Centers for Persons with HIVIAIDS, and public health authorities from throughout Cuba who dedicated their time and efforts to the interview process. This study is part of a project on HAART adherence, nutrition, and physical exercise in persons with HIVIAIDS, being conducted by researchers from the departments of Biostatistics and Informatics, Medical Care, and Epidemiology of the Pedro Kourí Tropical Medicine Institute, with funding from MINSAP and HIVOS, a Dutch nongovernmental organization. - - M

\section{REFERENCES}

1. UNAIDS. AIDS epidemic update 2009 [Internet] 2009 Nov [cited 2010 Jan 19]. Available from: http://data.unaids.org/pub/Report/2009/jc1700_ epi_update_2009_en.pdf

2. Estruch L, Santín M, Lantero MI, Ochoa R, Joanes J, Alé K, et al. República de Cuba. Informe nacional sobre los progresos realizados en la aplicación del UNGASS. La Habana [Internet] Geneva: UNAIDS; 2010 Mar [cited 2010 June 20]. 42 p. Available from: http://data.unaids.org/ pub/Report/2010/cuba_2010_country_progress_report_es.pdf. Spanish.

3. Pérez J, Pérez D, González I, Díaz Jidy M, Orta $M$, Aragonés $C$, et al. Approaches to the Management of HIVIAIDS in Cuba. Geneva: World Health Organization; 2004.
4. Aragonés López C, Campos Díaz JR, Sánchez Valdés L, Pérez Avila LJ. Grupos de Prevención del SIDA (GPSIDA): 15 años de trabajo sostenido en la prevención del VIH/SIDA. Rev Cubana Med Trop. 2007;59(3):261-9. Spanish.

5. Bayer R, Healton C. Controlling AIDS in Cuba. The logic of quarantine. N Engl J Med. 1989 Apr 13;320(15):1022-4.

6. Pérez-Stable EJ. Cuba's response to the HIV epidemic. Am J Public Health. 1991 May;81(5):563-7.

7. Scheper-Hughes N. AIDS, public health, and human rights in Cuba. Lancet. 1993 Oct 16:342(8877):965-7.

8. Pérez Ávila LJ, Pérez Correa DF, Orta Gutiérrez M, Martínez Rodríguez A, Luzardo C, Aragonés López C, et al. Tratamiento antirretroviral de alta eficiencia en pacientes cubanos con genéricos de producción nacional. II Foro en VIH/SIDA/ITS en América Latina y el Caribe. 2003 Apr 7-12; Havana, Cuba [Internet]. Havana: Pedro Kourí Institute of Tropical Medicine (CU); 2003 [cited 2011 Feb 1]. 12 p. Available from: http://www. foro2003.sld.cu/recursos/ver.php/Pérez $\% 20$ Avila?id=1065. Spanish

9. Haubrich RH, Little SJ, Currier JS, Forthal DN, Kemper CA, Beall GN, et al. The value of patientreported adherence to antiretroviral therapy in predicting virologic and immunologic response. California Collaborative Treatment Group. AIDS. 1999 Jun 18;13(9):1099-107.

10. Chesney MA, Ickovics J, Hecht FM, Sikipa G, Rabkin J. Adherence: a necessity for successful 
HIV combination therapy. AIDS. 1999;13 Suppl A:S271-8.

11. Chesney MA. Factors affecting adherence to antiretroviral therapy. Clin Infect Dis. 2000 Jun;30 Suppl 2:S171-6. Review.

12. Chesney M. Adherence to HAART regimens AIDS Patient Care STDS. 2003 Apr;17(4):169-77.

13. Bangsberg DR, Hecht FM, Charlebois ED, Zolopa AR, Holodniy M, Sheiner L, et al. Adherence to protease inhibitors, HIV-1 viral load, and development of drug resistance in an indigent population. AIDS. 2000 Mar 10;14(4):357-66.

14. Kalichman SC, Ramachandran B, Catz S. Adherence to combination antiretroviral therapies in HIV patients of low health literacy. J Gen Intern Med. 1999 May;14(5):267-73.

15. Bangsberg DR, Moss AR, Deeks SG. Paradoxes of adherence and drug resistance to HIV antiretroviral therapy. J Antimicrob Chemother. 2004 May;53(5):696-9.

16. Bangsberg DR, Perry S, Charlebois ED, Clark RA, Roberston M, Zolopa AR, et al. Nonadherence to highly active antiretroviral therapy predicts progression to AIDS. AIDS. 2001 Jun 15;15(9):1181-3.

17. García de Olalla P, Knobel H, Carmona A, Guelar A, López-Colomés JL, Caylà JA. Impact of adherence and highly active antiretroviral therapy on survival in HIV-infected patients. J Acquir Immune Defic Syndr. 2002 May 1;30(1):105-10.

18. Mehta S, Moore RD, Graham NMH. Potential factors affecting adherence with HIV therapy. AIDS. 1997 Nov 15;11(14):1665-70.

19. Murphy DA, Marelich WD, Hoffman D, Steers WN. Predictors of antiretroviral adherence. AIDS Care. 2004 May;16(4):471-84.

20. Cahn P, Vibhagool A, Schechter M, SotoRamirez L, Carosi G, Smaill F, et al. Predictors of adherence and virologic outcome in HIV-infected patients treated with abacavir- or indinavir-based triple combination HAART also containing lamivudine/zidovudine. Curr Med Res Opin. 2004 Jul;20(7):1115-23

21. Castro A. Adherence to Antiretroviral Therapy: Merging the Clinical and Social Course of AIDS. PLoS Med. 2005 Oct 4;2(12):e338

22. Wagner JH, Justice AC, Chesney M, Sinclair G, Weissman S, Rodriguez-Barradas M. Patientand provider-reported adherence: toward a clinically useful approach to measuring antiretroviral adherence. J Clin Epidemiol. 2001 Dec;54 Suppl 1:S91-8

23. Bangsberg DR, Hecht FM, Clague $\mathrm{H}$, Charlebois ED, Ciccarone D, Chesney $M$, et al. Provider assessment of adherence to HIV antiretroviral therapy. J Acquir Immune Defic Syndr. $2001 \mathrm{Apr}$ 15;26(5):435-42.

24. Nemes MIB, Carvalho HB, Souza MFM. Antiretroviral therapy adherence in Brazil. AIDS. 2004;18 Suppl 3:S15-20.

25. Weiss JJ. Attitudinal factors and adherence to protease inhibitor combination therapy. In: Aggleton P, Moatti JP, Prieur A, Sandfort T, Souteyrand Y, editors. AIDS in Europe-New Challenges for the Social Sciences. United Kingdom: Routledge; 2000. p. 45-56.

26. Moatti JP, Spire B. Living with HIVIAIDS and adherence to antiretroviral treatments. In: Aggleton P, Moatti JP, Prieur A, Sandfort T, Souteyrand Y, editors. AIDS in Europe- New Challenges for the Social Sciences. United Kingdom: Routledge; 2000. p. 57-73.

27. Abell N, Lewis S, Immel M. Adherence Attitude Inventory. The Body: the complete HIVIAIDS Re- source [Internet]. 2004 Aug [updated 2004 Aug 16; cited 2005 January 20]. Available from: http:// www.thebody.com/aacm/aai survey.html.

28. Remien RH, Hirky AE, Johnson MO, Weinhardt LS, Whittier D, Le GM. Adherence to Medication Treatment: A Qualitative Study of Facilitators and Barriers Among a Diverse Sample of HIV+ Men and Women in four US Cities. AIDS Behav. 2003 Mar;7(1):61-72

29. Sigma Research [Internet]. London: Stigma Research Anderson; c2011. The impact of combination therapy on the lives of people with HIV-a pilot study; 1999 [cited 2004 October 21];[about 1 screen]. Available from: http://www.sigmaresearch.org.uk/go.php?/projects/project01/.

30. Murphy DA, Sarr M, Durako SJ, Moscicki AB, Wilson CM, Muenz LR, et al. Barriers to HAART Adherence Among Human Immunodeficiency Virus-Infected Adolescents. Arch Pediatr Adolesc Med. 2003 Mar;157(3):249-55.

31. Race K, Wakeford E. Dosing on time: developing adherent practice with highly active anti-retroviral therapy. Cult Health Sex. 2000;2(2):213-28.

32. Chesney MA, Morin M, Sherr L. Adherence to HIV combination therapy. Soc Sci Med. 2000 Jun;50(11):1599-605.

33. Miller LG, Hays RD. Measuring adherence to antiretroviral medications in clinical trials. HIV Clin Trials. 2000 Jul-Aug;1(1):36-46.

34. Fletcher CV, Testa MA, Brundage RC, Chesney MA, Haubrich R, Acosta EP, et al. Four measures of antiretroviral medication adherence and virologic response in AIDS clinical trials group study 359. J Acquir Immune Defic Syndr. 2005 Nov 1;40(3):301-6.

35. Mannheimer SB, Matts J, Telzak E, Chesney M, Child C, Wu AW, et al. Quality of life in HIVinfected individuals receiving antiretroviral therapy is related to adherence. AIDS Care. 2005 Jan;17(1):10-22.

36. Cederfjäll C, Langius-Eklöf A, Lidman K, Wredling R. Self-reported adherence to antiretroviral treatment and degree of sense of coherence in a group of HIV-infected patients. AIDS Patient Care STDS. 2002 Dec;16(12):609-16.

37. Li L, Lee SJ, Wen Y, Lin C, Wan D, Jiraphongsa C. Antiretroviral therapy adherence among patients living with HIVIAIDS in Thailand. Nurs Health Sci. 2010 Jun;12(2):212-20.

38. Hosmer DW, Lemeshow S. Applied Logistic Regression. 2nd ed. New York: John Wiley \& Sons; 1989.

39. Gifford AL, Bormann JE, Shively MJ, Wright BC, Richman DD, Bozzette SA. Predictors of selfreported adherence and plasma HIV concentrations in patients on multidrug antiretroviral regimens. J Acquir Immune Defic Syndr. 2000 Apr 15;23(5):386-95.

40. Chesney MA, Ickovics JR, Chambers DB, Gifford AL, Neidig J, Zwickl B, et al. Self-reported adherence to antiretroviral medications among participants in HIV clinical trials: the AACTG adherence instruments. Patient Care Committee \& Adherence Working Group of the Outcomes Committee of the Adult AIDS Clinical Trials Group (AACTG). AIDS Care. 2000 Jun;12(3):255-66.

41. Spire B, Duran S, Souville M, Leport C, Raffi F, Moatti JP, et al. Adherence to highly active antiretroviral therapies (HAART) in HIV-infected patients: from a predictive to a dynamic approach. Soc Sci Med. 2002 May;54(10):1481-96.

42. Bonolo P de F, Cesar CC, Acúrcio FA, Ceccato MG, de Pádua CA, Alvares J, et al. Nonadherence among patients initiating anti- retroviral therapy: a challenge for health professionals in Brazil. AIDS. 2005 Oct;19 Suppl $4:$ S5-13.

43. Pinheiro CA, de-Carvalho-Leite JC, Drachler ML, Silveira VL. Factors associated with adherence to antiretroviral therapy in HIVIAIDS patients: a cross-sectional study in Southern Brazil. Braz J Med Biol Res. 2002 Oct;35(10):1173-81.

44. Cingolani A, Antinori A, Rizzo MG, Murri R, Ammassari A, Baldini $F$, et al. Usefulness of monitoring HIV drug resistance and adherence in individuals failing highly active antiretroviral therapy: a randomized study (ARGENTA). AIDS. 2002 Feb 15;16(3):369-79.

45. Carrieri P, Spire B, Duran S, Katlama C, Peyramond D, François C, et al. Health-Related Quality of Life After 1 Year of Highly Active Antiretroviral Therapy. J Acquir Immune Defic Syndr. 2003 Jan 1;32(1):38-47.

46. Carrieri P, Cailleton V, Le Moing V, Spire B, Dellamonica $P$, Bouvet $E$, et al. The dynamic of adherence to highly active antiretroviral therapy: Results From the French National APROCO cohort. J Acquir Immune Defic Syndr. 2001 Nov 1;28(3):232-9.

47. Charalambous S, Innes C, Muirhead D, Kumaranayake L, Fielding K, Pemba L, et al. Evaluation of a workplace HIV treatment programme in South Africa. AIDS. 2007 Jul;21 Suppl 3:S73-8.

48. Weiser S, Wolfe W, Bangsberg D, Thior I, Gilbert $\mathrm{P}$, Makhema J, et al. Barriers to antiretroviral adherence for patients living with HIV infection and AIDS in Botswana. J Acquir Immune Defic Syndr. 2003 Nov 1;34(3):281-8.

49. Spacek LA, Shihab HM, Kamya MR, Mwesigire $\mathrm{D}$, Ronald $\mathrm{A}$, Mayanja $\mathrm{H}$, et al. Response to Antiretroviral Therapy in HIV-Infected Patients Attending a Public, Urban Clinic in Kampala, Uganda. Clin Infect Dis. 2006 Jan 15;42(2):252-9.

50. Bajunirwe F, Arts EJ, Tisch DJ, King $\mathrm{CH}$, Debanne SM, Sethi AK. Adherence and treatment response among HIV-1-infected adults receiving antiretroviral therapy in a rural government hospital in Southwestern Uganda. J Int Assoc Physicians AIDS Care (Chic). 2009 MarApr;8(2):139-47.

51. Collazos J, Asensib V, Cartón JA. Sex differences in the clinical, immunological and virological parameters of HIV-infected patients treated with HAART. AIDS. 2007 Apr 23;21(7):835-43

52. Paterson DL, Swindells S, Mohr J, Brester M, Vergis EN, Squier C, et al. Adherence to protease inhibitor therapy and outcomes in patients with HIV infection. Ann Intern Med. 2000 Jul 4;133(1):21-30

53. Malta M, Petersen ML, Clair S, Freitas F, Bastos FI. Adherence to antiretroviral therapy: a qualitative study with physicians from Rio de Janeiro, Brazil. Cad Saude Publica. 2005 SepOct;21(5):1424-32.

54. Kleeberger CA, Phair JP, Strathdee SA, Detels R, Kingsley L, Jacobson LP. Determinants of heterogeneous adherence to HIV-antiretroviral therapies in the Multicenter AIDS Cohort Study. J Acquir Immune Defic Syndr. 2001 Jan $1 ; 26(1): 82-92$

55. Catz SL, Kelly JA, Bogart LM, Benotsch EG, McAuliffe TL. Patterns, correlates, and barriers to medication adherence among persons prescribed new treatments for HIV disease. Health Psychol. 2000 Mar;19(2):124-33.

56. Woods SP, Dawson MS, Weber E, Gibson S, Grant I, Atkinson JH, et al. Timing is everything: 
antiretroviral nonadherence is associated with impairment in time-based prospective memory. J Int Neuropsychol Soc. 2009 Jan;15(1):42-52.

57. Marco A, Knobel H, Guelar A. La adhesión al tratamiento antirretroviral; una perspectiva global del problema y posibles soluciones. Enf Emerg. 2000;2(1):45-53. Spanish.

\section{THE AUTHORS}

Carlos Aragonés López (Corresponding author: aragones@ipk.sld.cu), computer sciences engineer with a master's degree in epidemiology. Associate researcher and head of the Department of Biostatistics and Informatics, Pedro Kourí Tropical Medicine Institute, Havana, Cuba. National coordinator, AIDS Prevention Group.

Lizet Sánchez Valdés, physician specializing in epidemiology with a doctorate in medical sciences. Associate researcher, Pedro Kourí Tropical Medicine Institute, Havana, Cuba.

Jorge Raúl Campos Díaz, technician. Department of Biostatistics and Informatics, Pe- dro Kourí Tropical Medicine Institute, Havana, Cuba. HIVIAIDS health promoter and national vice-coordinator, AIDS Prevention Group).

Jorge Pérez Ávila, physician specializing in pharmacology, with a master's degree in clinical pharmacology. Director and associate researcher, Pedro Kourí Tropical Medicine Institute, Havana, Cuba.

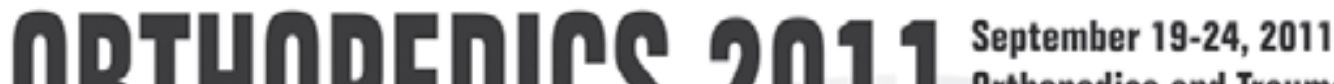 Orthopedics and Traumatology Events Center [ORTOP] Havana, Cuba
}

\author{
Themes \\ Minimal-access surgery in orthopedics and traumatology \\ Total arthroplasty in shoulder and elbow \\ Advances in arthroplastic surgery \\ Management of pelvic ring fractures and their complications
}

\section{Pre-Congress Courses}

External fixator systems by Prof. Rodrigo Álvarez Cambras Current topics in bone tumor management
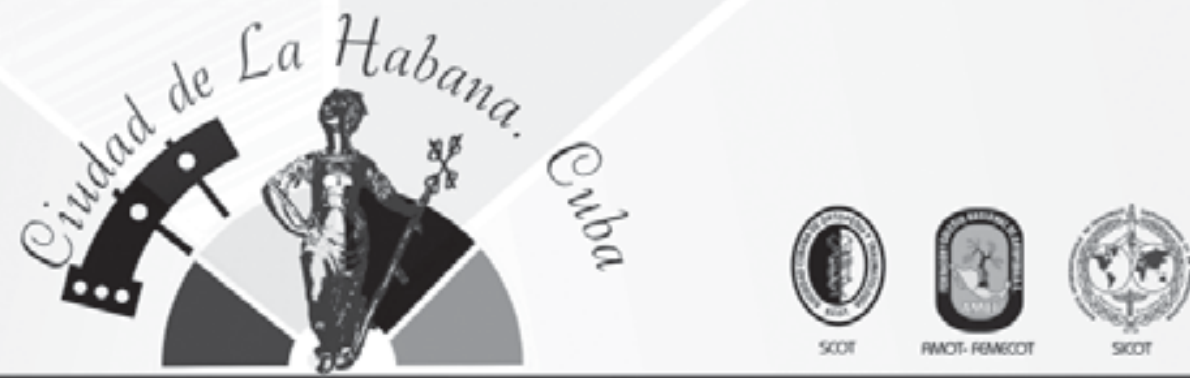

For Registration and Information, contact: Prof. Mercedes Guzmán López - scot@fpais.sid.cu 